\title{
PREVALENCE OF HCV, HBV AND HIV IN INSTITUTIONALIZED MENTAL ILLNESS PATIENTS AT ASWAN GOVERNORATE
}

\author{
By
Atef Mohammed Mahmmoud, Mohammed Bastawy, Sherif Ali Abd El- Aziz and Abd Allah Mustafa Jaafar* \\ Department of Hepatogastroentrology \& Infectioys Diseases and Clinical Pathology*, \\ Faculty of Medicine, Al-Azhar University, Egypt \\ Corresponding author: Atef Mohammed Mahmmoud, E-mail: dratef@yahoo.com
}

\begin{abstract}
Background: HIV, hepatitis B, and hepatitis C are serious infections, but can be treated. The prognosis is much improved by earlier detection and treatment. Prevalence studies have shown that serious mental illness is a risk factor for blood-borne virus infection.

Objective: To evaluate the prevalence of blood borne viral infection in people with psychological disorders attending Aswan Governate.

Patients and methods: This across sectional study included 180 patients (150 males and 30 females) with moderate to severe mental illness from the attendants of the Outpatient Clinic of Psychatric Department, Neuro-Psychiatric Hospital, Aswan Governorate, from May 2019 to November 2019. The etiological diagnosis of the studied group was schizophrenia (males $=64$, females $=9)$, depression $($ males $=30$, females $=9)$ and general anxiety disorder (males $=16$, females $=6$ ).

Results: As regard HCV Abs, there were 157 negative patients (87.2\%) and 23 positive patients (12.8\%) in the studied patients. As regard HBs Ag, there were 162 negative patients $(90 \%)$, and 18 positive patients $(10 \%)$ in the studied patients. As regard HIV Abs, there were 170 negative patients (94.4\%), and 10 positive patients $(5.6 \%)$ in the studied patients. There was no statistical significant relation between sex and virology markers in all studied patients (p-value >0.05).

Conclusion: People with serious mental illness are at risk of blood-borne viral infections. Serious mental illness is unlikely to be a sole risk factor and risk of blood-borne viral infection is probably multifactorial, and associated with low socioeconomic status, drug and alcohol misuse, ethnic origin, and sex. Health providers should routinely discuss sexual health and risks for blood-borne viruses (including risks related to drug misuse) with people who have serious mental illness, as well as offering testing and treatment for those at risk.
\end{abstract}

Keywords: Depression, General anxiety disorder, Hepatitis B, Hepatitis C, Mental illness and schizophrenia.

\section{INTRODUCTION}

Hepatitis $\mathrm{C}$ virus (HCV) infection is a major public health burden in Egypt, where it bears the highest prevalence rate in the world. The prevalence rates of psychiatric illness in patients with $\mathrm{HCV}$ infection are higher than those rates in the general population, and the prevalence of $\mathrm{HCV}$ infection in patients with severe mental illness may be as high as 9 times that of the general population (Rifai et al., 2010).

HBV is the tenth leading cause of death worldwide. However, viral hepatitis 
is a major public health threat in Egypt, but little is known about the epidemiology of hepatitis B (HBV). According Ismail et al. HBV prevalence among adults aged 15-59 in Egypt is $1.4 \%$, but despite exceptionally high $\mathrm{HCV}$ prevalence, the HBV-HCV co-infection rate is $0.06 \%$ and geographical distributions of the two infections differ markedly (Ismail et al., 2017).

Psychological reactions among patients with hepatitis B infection are considerably different and affect their decision about treating and following up the disease. Moreover, psychological problems are prevalent among patients with chronic hepatitis B virus infection, in as much as anxiety and depression among them are significantly more than healthy people (Valizadeh et al., 2016).

Although people with serious mental illnesses have a high risk of contracting blood-borne viral infections, sexual health has largely been neglected by researchers and policy makers involved in mental health. Failure to address this shortcoming could increase morbidity and mortality as a result of undetected and untreated infection (Hughes et al., 2016).

The present work aimed to evaluate the prevalence of blood borne viral infection in people with psychiatric disorders attending Aswan Governorate.

\section{PATIENTS AND METHODS}

This across sectional study included 180 patients (150 males and 30 females) with moderate to severe mental illness from the attendants of the Outpatient Clinic of Psychiatric Department, NeuroPsychiatric Hospital, Aswan Governorate, from May 2019 to November 2019. The etiological diagnosis of the studied group were schizophrenia (males $=64$ and females $=9$ ), depression (males $=30$, females $=9$ ) and general anxiety disorder (males $=16$ and females=6). Patients gave written informed cnseits.

Our study was subjected to patients with psychiatric disorders were studied for their association with $\mathrm{HCV} \& \mathrm{HBV}$ and HIV infection.

Inclusion criteria: Age: more than 20 years old, and all patients attending outpatient clinic should be diagnosed with a lifetime diagnosis of a serious mental illness.

Exclusion criteria: Pregnant women, extra-hepatic malignancy except after 2 years of disease-free interval, patients who received a liver transplant just before the study period and patients with severe form of extra-hepatic manifestation.

\section{All studied individuals were subjected} to:

1. Full medical history include: Name, age, sex, occupation, diseases history, past history, family history, infectious disease screening history, and engagement in high-risk behaviors including IV drug use, unprotected sexual activity and substance use patterns.

\section{Clinical examination.}

\section{Investigations include:}

- HCV antibody.

- HBV antigen (HBV surface Ag).

- HIV antibody.

- Pelvic-abdominal ultrasound. 
- Liver function tests: (Serum Albumin, Total and Direct serum Bilirubin, Aspartate aminotransferase (AST), Alanine aminotransferase (ALT), Prothrombin time and INR.

- Kidney function tests (urea, creatinine).

- Complete blood count (CBC).

- Fasting blood sugar (FBS).

\section{Statistical analysis:}

Data were verified, coded by the researcher and analyzed using IBM-SPSS Statistics for windows, version 23.0 (Copyright IBM Corp., Armonk, N.Y.,
USA. 2015). Descriptive statistics: Means, standard deviations, medians, ranges and percentages were calculated. Test of significances: Chi-square test was used to compare the difference in distribution of frequencies among different groups. For continuous variables; independent t-test analysis was carried out to compare the means of dichotomous data. There was no specific calculation of the sample size. A significant p-value was considered when it was equal or less than 0.05 .

\section{RESULTS}

The description of $\mathrm{HCV}$ Abs, $\mathrm{HBs} \mathrm{Ag}$ and HIV Abs in studied patients. As regard $\mathrm{HCV}$ Abs, there were 157 negative patients $(87.2 \%)$ and 23 positive patients $(12.8 \%)$ in the studied patients. As regard $\mathrm{HBs} \mathrm{Ag}$, there were 162 negative patients $(90 \%)$ and 18 positive patients $(10 \%)$ in the studied patients. As regard HIV Abs, there were 170 negative patients $(94.4 \%)$ and 10 positive patients $(5.6 \%)$ in the studied patients. As regard Co-infection, there were 2 patients $(1.1 \%)$ with $\mathrm{HCV}$ $\mathrm{Ab}+\mathrm{HBs}$ Ag, 1 patient $(0.6 \%)$ with $\mathrm{HCV}$ $\mathrm{Ab}+\mathrm{HIV} \mathrm{Ab}$ and 3 patients (1.7\%) with HBs Ag + HIV Ab in the studied patients (Table 1).

Table (1): Description of HCV Abs, HBs Ag and HIV Abs in all studied patients

\begin{tabular}{|c|c|c|c|}
\hline \multirow{2}{*}{ HCV Abs } & Variable s & \multicolumn{2}{c|}{ Studied patients (N = 180) } \\
\cline { 2 - 4 } & Negative & 157 & $87.2 \%$ \\
\hline \multirow{3}{*}{ HBs Ag } & Positive & 23 & $12.8 \%$ \\
\hline \multirow{3}{*}{ HIV Abs } & Negative & 162 & $90 \%$ \\
\cline { 2 - 4 } & Positive & 18 & $10 \%$ \\
\cline { 2 - 4 } & Negative & 170 & $94.4 \%$ \\
\hline \multirow{3}{*}{ Co-infection } & Positive & 2 & $5.6 \%$ \\
\cline { 2 - 4 } & HCV Ab + HBs Ag & 1 & $1.1 \%$ \\
\cline { 2 - 4 } & HCV Ab + HIV Ab & 3 & $0.6 \%$ \\
\cline { 2 - 4 } & HBs Ag + HIV Ab & 0 & $1.7 \%$ \\
\cline { 2 - 4 } & HCV Ab + HBs Ag + HIV Ab & & $0 \%$ \\
\hline
\end{tabular}

There was no statistical significant relation between sex and virology markers in studied schizophrenia patients ( $\mathrm{p}$-value
$>0.05)$. As regard Co-infection, there was 1 male patient $(0.02 \%)$ with $\mathrm{HCV} \mathrm{Ab}+$ HBs Ag in the studied patients (Figure 1). 


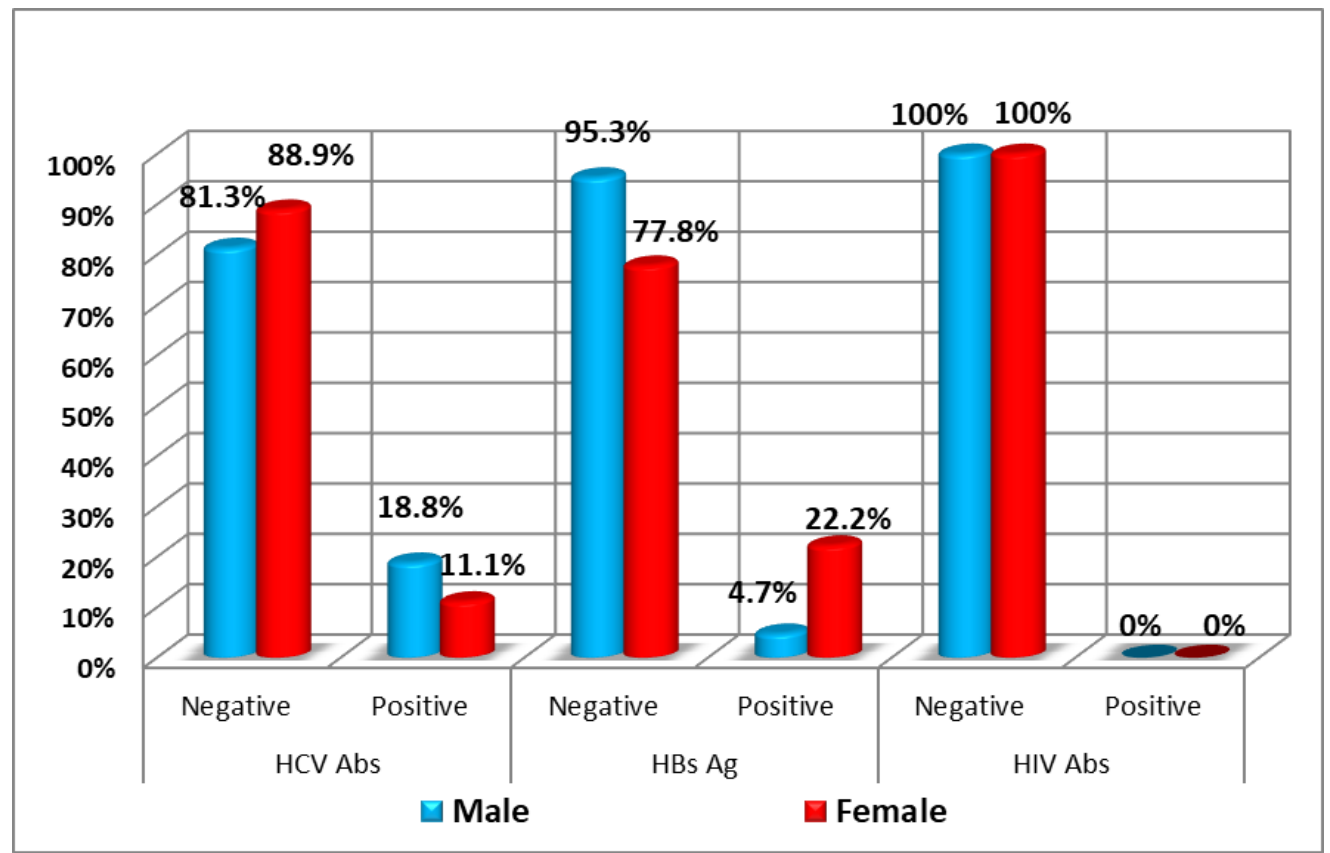

Figure (1): Relation between sex and studied virology markers in schizophrenia patients

There was no statistical significant relation between sex and virology markers in studied depression patients ( $\mathrm{p}$-value > 0.05). As regard Co-infection, there was 1 male patient $(0.03 \%)$ with $\mathrm{HCV} \mathrm{Ab}+\mathrm{HBs}$ $\mathrm{Ag}$ and 1 female patient $(11.1 \%)$ with HBs Ag + HIV Ab in the studied patients (Figure 2).

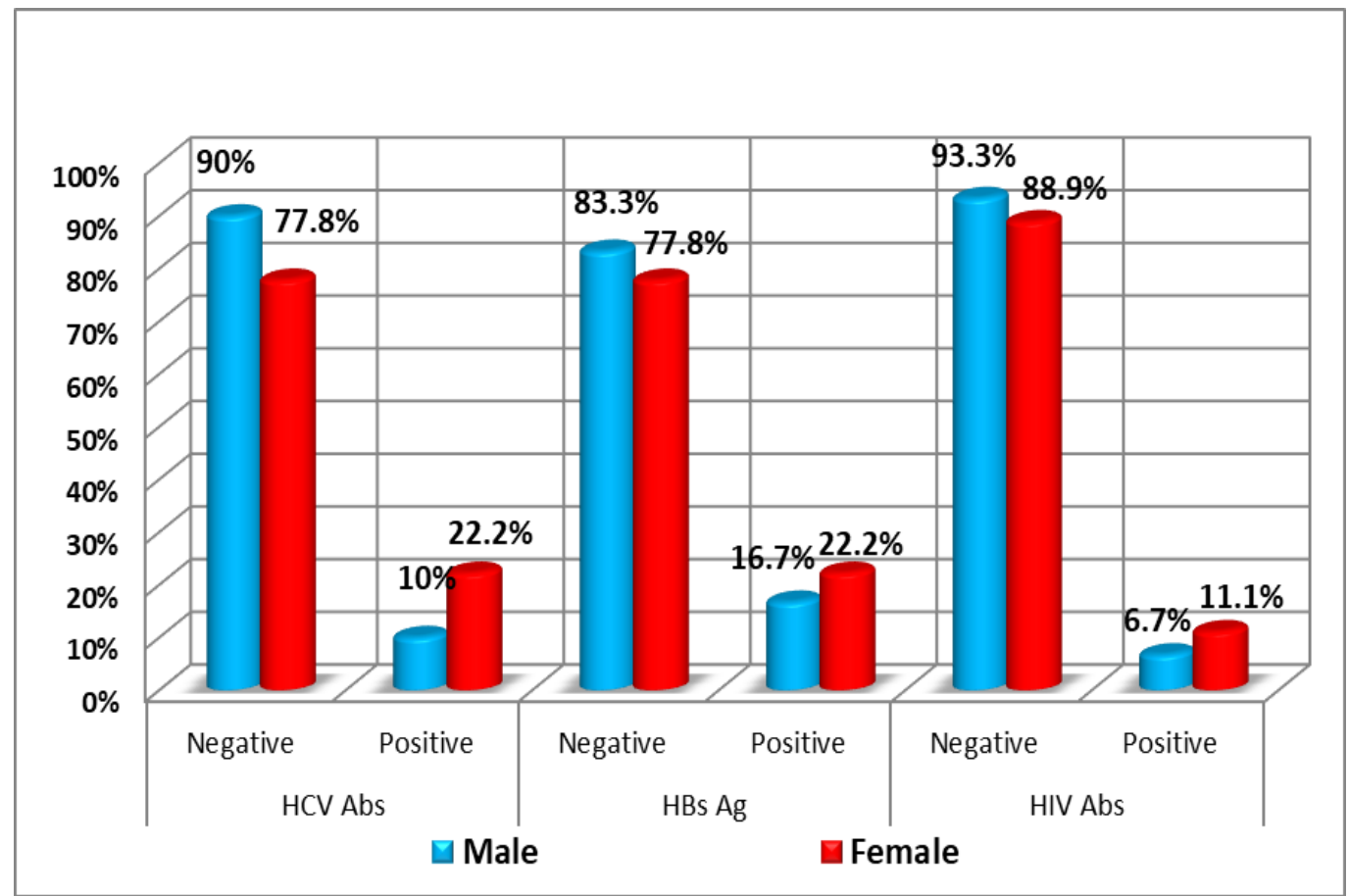

Figure (2): Relation between sex and studied virology markers in depression patients 
There was no statistical significant relation between sex and virology markers in studied general anxiety disorder patients ( $\mathrm{p}$-value $>0.05$ ). As regard Co- infection, there were no males or females co-infected with viral markers in the studied patients (Table 2).

Table (2): Relation between sex and studied virology markers in general anxiety disorder patients

\begin{tabular}{|c|c|c|c|c|c|c|c|}
\hline \multirow{2}{*}{\multicolumn{2}{|c|}{ Viral markers }} & \multicolumn{4}{|c|}{ Sex } & \multirow[b]{2}{*}{$\mathbf{X}^{2}$} & \multirow[b]{2}{*}{ P-value } \\
\hline & & \multicolumn{2}{|c|}{$\begin{array}{c}\text { Male } \\
(\mathrm{N}=\mathbf{1 6})\end{array}$} & \multicolumn{2}{|c|}{$\begin{array}{l}\text { Female } \\
(N=6)\end{array}$} & & \\
\hline \multirow{2}{*}{ HC V Abs } & Negative & 14 & $87.5 \%$ & 6 & $100 \%$ & \multirow{2}{*}{0.825} & \multirow{2}{*}{0.364} \\
\hline & Positive & 2 & $12.5 \%$ & 0 & $0 \%$ & & \\
\hline \multirow{2}{*}{ HBs Ag } & Negative & 14 & $87.5 \%$ & 6 & $100 \%$ & \multirow{2}{*}{0.825} & \multirow{2}{*}{0.364} \\
\hline & Positive & 2 & $12.5 \%$ & 0 & $0 \%$ & & \\
\hline \multirow{2}{*}{ HIV Abs } & Negative & 16 & $100 \%$ & 6 & $100 \%$ & \multirow{2}{*}{0} & \multirow{2}{*}{1} \\
\hline & Positive & 0 & $0 \%$ & 0 & $0 \%$ & & \\
\hline \multirow{4}{*}{ Co-infection } & $\mathrm{C}+\mathrm{B}$ & 0 & $0 \%$ & 0 & $0 \%$ & \multirow{4}{*}{----- } & \multirow{4}{*}{---- } \\
\hline & $\mathbf{C}+\mathbf{I}$ & 0 & $0 \%$ & 0 & $0 \%$ & & \\
\hline & B + I & 0 & $0 \%$ & 0 & $0 \%$ & & \\
\hline & $\mathrm{C}+\mathrm{B}+\mathrm{I}$ & 0 & $0 \%$ & 0 & $0 \%$ & & \\
\hline
\end{tabular}

No statistical significant relation (pvalue $>0.05)$ between sex and studied virology markers in mania patients. As regard Co-infection, there were no males or females co-infected with viral markers in the studied patients (Table 3).

Table (3): Relation between sex and studied virology markers in mania patients

\begin{tabular}{|c|c|c|c|c|c|c|c|}
\hline \multirow{2}{*}{\multicolumn{2}{|c|}{$\underbrace{\text { Mania patients }}_{\text {Viral markers }}$}} & \multicolumn{4}{|c|}{ Sex } & \multirow[b]{2}{*}{$\mathbf{X}^{2}$} & \multirow[b]{2}{*}{ P-value } \\
\hline & & \multicolumn{2}{|c|}{$\begin{array}{c}\text { Male } \\
(\mathrm{N}=\mathbf{1 0})\end{array}$} & \multicolumn{2}{|c|}{$\begin{array}{c}\text { Female } \\
(\mathbf{N}=2)\end{array}$} & & \\
\hline \multirow{2}{*}{ HCV Abs } & Negative & 10 & $100 \%$ & 2 & $100 \%$ & \multirow{2}{*}{0} & \multirow{2}{*}{1} \\
\hline & Positive & 0 & $0 \%$ & 0 & $0 \%$ & & \\
\hline \multirow{2}{*}{ HBs Ag } & Negative & 9 & $90 \%$ & 2 & $100 \%$ & \multirow{2}{*}{0.21} & \multirow{2}{*}{0.640} \\
\hline & Positive & 1 & $10 \%$ & 0 & $0 \%$ & & \\
\hline \multirow{2}{*}{ HIV Abs } & Negative & 10 & $100 \%$ & 2 & $100 \%$ & \multirow{2}{*}{0} & \multirow{2}{*}{1} \\
\hline & Positive & 0 & $0 \%$ & 0 & $0 \%$ & & \\
\hline \multirow{4}{*}{ Co-infection } & $C+B$ & 0 & $0 \%$ & 0 & $0 \%$ & & \\
\hline & $C+I$ & 0 & $0 \%$ & 0 & $0 \%$ & & \\
\hline & $\mathbf{B}+\mathbf{I}$ & 0 & $0 \%$ & 0 & $0 \%$ & & \\
\hline & $\mathrm{C}+\mathrm{B}+\mathrm{I}$ & 0 & $0 \%$ & 0 & $0 \%$ & & \\
\hline
\end{tabular}

No statistical significant relation (pvalue > 0.05) between sex and studied virology markers in OCD patients. As regard Co-infection, there was 1 male patient $(14.3 \%)$ with $\mathrm{HCV} \mathrm{Ab}+\mathrm{HIV} \mathrm{Ab}$ in the studied patients (Table 4). 
Table (4): Relation between sex and studied virology markers in OCD patients

\begin{tabular}{|c|c|c|c|c|c|c|c|}
\hline \multirow{2}{*}{\multicolumn{2}{|c|}{$\underbrace{}_{\text {Viral markers }}$ OCD patients }} & \multicolumn{4}{|c|}{ Sex } & \multirow[b]{2}{*}{$\mathbf{X}^{2}$} & \multirow[b]{2}{*}{ P-value } \\
\hline & & \multicolumn{2}{|c|}{$\begin{array}{c}\text { Male } \\
(\mathbf{N}=7)\end{array}$} & \multicolumn{2}{|c|}{$\begin{array}{c}\text { Female } \\
(\mathbf{N}=2)\end{array}$} & & \\
\hline \multirow{2}{*}{ HCV Abs } & Negative & 6 & $85.7 \%$ & 2 & $100 \%$ & \multirow{2}{*}{0.32} & \multirow{2}{*}{0.571} \\
\hline & Positive & 1 & $14.3 \%$ & 0 & $0 \%$ & & \\
\hline \multirow{2}{*}{ HBs Ag } & Negative & 7 & $100 \%$ & 2 & $100 \%$ & \multirow{2}{*}{0} & \multirow{2}{*}{1} \\
\hline & Positive & 0 & $0 \%$ & 0 & $0 \%$ & & \\
\hline \multirow{2}{*}{ HIV Abs } & Negative & 6 & $85.7 \%$ & 1 & $50 \%$ & \multirow{2}{*}{1.14} & \multirow{2}{*}{0.284} \\
\hline & Positive & 1 & $14.3 \%$ & 1 & $50 \%$ & & \\
\hline \multirow{4}{*}{ Co-infection } & $C+B$ & 0 & $0 \%$ & 0 & $0 \%$ & \multirow{4}{*}{0} & \multirow{4}{*}{1} \\
\hline & $\mathrm{C}+\mathrm{I}$ & 1 & $14.3 \%$ & 0 & $0 \%$ & & \\
\hline & B + I & 0 & $0 \%$ & 0 & $0 \%$ & & \\
\hline & $\mathbf{C}+\mathbf{B}+\mathbf{I}$ & 0 & $0 \%$ & 0 & $0 \%$ & & \\
\hline
\end{tabular}

\section{DISCUSSION}

A significant proportion of people with severe mental diseases, are infected with HIV at some time in their lives with epidemiologically representative studies finding around $6.2-29.10 \%$ of people with severe mental diseases had comorbid HIV infections. The prevalence of hepatitis $\mathrm{B}$ and hepatitis $\mathrm{C}$ viruses in people with severe mental diseases is significantly higher. According to different studies, the prevalence ranges from 7.45 to $47.5 \%$ and 6.2-29.8\% for hepatitis B and hepatitis C, respectively (Hughes et al., 2016).

The present study showed the description of $\mathrm{HCV}$ Abs, $\mathrm{HBs} \mathrm{Ag}$ and HIV Abs in studied patients. As regard $\mathrm{HCV}$ Abs, there were $87.2 \%$ negative patients and $12.8 \%$ positive patients in the studied patients. As regard HBs Ag, there were $90 \%$ negative patients and $10 \%$ positive patients in the studied patients. As regard HIV Abs, there were 94.4\% negative patients and $5.6 \%$ positive patients in the studied patients. As regard Co-infection, there were $1.1 \%$ patients with $\mathrm{HCV} \mathrm{Ab}+\mathrm{HBs} \mathrm{Ag}, 0.6 \%$ patient with $\mathrm{HCV} \mathrm{Ab}+\mathrm{HIV} \mathrm{Ab}$ and $1.7 \%$ patients with $\mathrm{HBs} \mathrm{Ag}+\mathrm{HIV} \mathrm{Ab}$ in the studied patients.

These results resembled that of Rosenberg et al. (2013) who studied the prevalence of HIV, hepatitis B, and hepatitis $\mathrm{C}$ in people within severe mental illness, and found that the prevalence of HIV infection in his sample of severe mental illness was $3.1 \%$; prevalence rates of $\mathrm{HCV}$ was $18.4 \%$ and HBV was $14.6 \%$. Huy et al. (2014) studied HBV, HCV and AIDS coinfection among severe mental patients found that $5 \%$ had $\mathrm{HCV} \mathrm{Ab}+$ HBs Ag, $2.5 \%$ had HCV Ab + HIV Ab and $3 \%$ of mental patients had HBs Ag + HIV Ab. Other results of Durotoye et al. (2014) disagreed with our results and found that HIV was $12 \%$, HBV was $25 \%$ and $\mathrm{HCV}$ was $21 \%$.

The current work showed that there was no statistical significant relation between sex and virology markers in all studied patients. As regard co-infection, there were $0.1 \%$ male patients with $\mathrm{HCV}$ $\mathrm{Ab}+\mathrm{HBs} \mathrm{Ag}, 0.1 \%$ male and $0.01 \%$ female with $\mathrm{HCV} \mathrm{Ab}+\mathrm{HIV} \mathrm{Ab}$ and $0.1 \%$ 
patients with $\mathrm{HBs} \mathrm{Ag}+\mathrm{HIV} \mathrm{Ab}$ in the studied patients.

These results were in agreement with Silberstein et al. (2017) who studied HIV, HBV and HCV seroprevalence among homeless patients admitted to a psychiatric inpatient unit, and found that there was no significant difference between virology markers and psychiatric patients.

Huy et al. (2014) who found also no statistical significant difference between males and females severe mental patients regarding co-infection with our viral markers.

The current work showed that there was no statistical significant relation between sex and virology markers in studied schizophrenia patients. As regard co-infection, there was $0.02 \%$ male patient with $\mathrm{HCV} \mathrm{Ab}+\mathrm{HBs} \mathrm{Ag}$ in the studied patients. Similar results were found by Kneeland and Fatemi (2013) who studied the viral infection, inflammation and schizophrenia.

Mazaheri-Tehrani et al. (2014) studied viral infection in psychiatric patients and comparison of sex groups with healthy controls, and found that there was a significant difference among males group, females group and controls group. As regard schizophrenia patients co-infected with viral markers, Huy et al. (2014) found also no statistical significant difference between males and females.

The current work showed that there was no statistical significant relation between sex and virology markers in studied depression patients. As regard Coinfection, there was $0.03 \%$ male patient with $\mathrm{HCV} \mathrm{Ab}+\mathrm{HBs} \mathrm{Ag}$ and $11.1 \%$ female patient with $\mathrm{HBs} \mathrm{Ag}+\mathrm{HIV} \mathrm{Ab}$ in the studied patients.

Similar results were found also in the work of Oquendo et al. (2013) who studied sex differences in clinical predictors of depression: a prospective study. As regard depression patients coinfected with viral markers, Huy et al. (2014) found also no statistical significant difference between males and females.

Maeng and Hong (2019) studied inflammation as the potential basis in depression, disagree with our results as they found a significant statistical difference between males and females in studied sex group as females were more likely than males to experience a major depressive episodes.

The present study showed that there was no statistical significant relation between sex and virology markers in studied general anxiety disorder patients. As regard co-infection, there were no males or females co-infected with viral markers in the studied patients. These results were in accordance with that of Maron and Nutt (2017) who studied biological markers of generalized anxiety disorder and found similar results.

As regard depression patients coinfected with viral markers, Huy et al. (2014) found also no statistical significant difference between males and females.

The current study showed that there was no statistical significant relation between sex and studied virology markers in mania patients. As regard co-infection, there were no males or females coinfected with viral markers in the studied patients. 
Chong et al. (2018) studied that association of viral hepatitis and bipolar disorder: a nationwide population-based study; found also similar results regarding mania patients.

As regard mania patients co-infected with viral markers, Huy et al. (2014) found also no statistical significant difference between males and females.

The present study showed that there was no statistical significant relation between sex and studied virology markers in OCD patients. As regard co-infection, there was $14.3 \%$ male patient with $\mathrm{HCV}$ $\mathrm{Ab}+\mathrm{HIV} \mathrm{Ab}$ in the studied patients.

Also, Campos et al. (2016) studied HIV, syphilis, and hepatitis B and C prevalence among patients with mental illness and found that there was no statistical significant relation between sex and studied virology markers in OCD patients.

As regard OCD patients co-infected with viral markers, Huy et al. (2014) found also no statistical significant difference between males and females.

Finally, the current study showed that there was no statistical significant relation between sex and mental disorders in studied patients.

\section{CONCLUSION}

People with serious mental illness are at risk of blood-borne viral infections. Serious mental illness is unlikely to be a sole risk factor and risk of blood-borne viral infection is probably multifactorial and associated with low socioeconomic status, drug and alcohol misuse, ethnic origin, and sex. Health providers should routinely discuss sexual health and risks for blood-borne viruses (including risks related to drug misuse) with people who have serious mental illness, as well as offering testing and treatment for those at risk.

\section{REFERENCES}

1. Campos LN, Guimarães MDC, Carmo RA, Melo APS, Oliveira HND and Elkington K. (2016): HIV, syphilis, and hepatitis $\mathrm{B}$ and $\mathrm{C}$ prevalence among patients with mental illness. Cadernos de saúde pública, 24: 607-620.

2. Chong LW, Hsu CC, Lee CY, Chou RH, Lin CL and Chang KH. (2018): Association of viral hepatitis and bipolar disorder: a nationwide population-based study. Journal of Translational Medicine, 16(1): 173-79.

3. Durotoye IA, Issa BA, Fadeyi A, Yussuf AD, Salami AK and Shittu OA. (2014): Sero-prevalence of HIV and hepatitis B and C among mentally ill patients attending a tertiary hospital in Nigeria. Annals of African Medicine, 13(4): 210-18.

4. Hughes E, Bassi S, Gilbody S, Bland M and Martin F. (2016): Prevalence of HIV, hepatitis $\mathrm{B}$, and hepatitis $\mathrm{C}$ in people with severe mental illness: a systematic review and meta-analysis. The Lancet Psychiatry, 3(1): 40-48.

5. Huy BV, Vernavong $K$ and Kính $N V$. (2014): HBV, HCV and AIDS coinfection among severe mental patients in the National Hospital of Tropical Diseases, Vietnam. AIDS Research and Treatment, 14: 36-45.

6. Ismail SA, Cuadros DF and Benova L. (2017): Hepatitis B in Egypt: A crosssectional analysis of prevalence and risk factors for active infection from a nationwide survey. Liver International, 37(12): 1814-1822. 
7. Kneeland RE and Fatemi SH. (2013): Viral infection, inflammation and schizophrenia. Progress in NeuroPsychopharmacology and Biological Psychiatry, 42: 35-48.

8. Maeng SH and Hong H. (2019): Inflammation as the potential basis in depression. International Neurourology Journal, 23(2): 63-71.

9. Maron E and Nutt D. (2017): Biological markers of generalized anxiety disorder. Dialogues in Clinical Neuroscience, 19(2): 147-153.

10. Mazaheri-Tehrani E, Maghsoudi N, Shams J, Soori H, Atashi $H$ and Motamedi F. (2014): Viral infection in psychiatric patients and comparison of sex groups with healthy controls in Iran. Virology Journal, 11(1): 161-67.

11. Oquendo MA, Turret J, Grunebaum MF, Burke AK, Poh E and Stevenson E. (2013): Sex differences in clinical predictors of depression: a prospective study. Journal of Affective Disorders, 150(3): 1179-1183.
12. Rifai MA, Gleason $O C$ and Sabouni $D$. (2010): Psychiatric care of the patient with hepatitis $\mathrm{C}$ : a review of the literature. Primary Care Companion to the Journal of Clinical Psychiatry, 12(6): 56-63.

13. Rosenberg SD, Goodman LA, Osher FC, Swartz MS, Essock SM and Butterfield MI. (2013): Prevalence of HIV, hepatitis $\mathrm{B}$, and hepatitis $\mathrm{C}$ in people with severe mental illness. American Journal of Public Health, 91(1): 31-39.

14. Silberstein C, Galanter M, Marmor M, Lifshutz $H$ Krasinski $K$ and Franco $H$. (2017): HIV, HBV and HCV seroprevalence among homeless patients admitted to a psychiatric inpatient unit. Am J Psychiatry, 20(5):101-13.

15. Valizadeh L, Zamanzadeh V, Negarandeh R, Zamani F, Hamidia A and Zabihi A. (2016): Psychological reactions among patients with chronic hepatitis B: A qualitative study. Journal of Caring Sciences, 5(1): 57-63. 
إنتشار فيروس إلتهاب الكبد الوبائي بي و سي وفيروس نقص

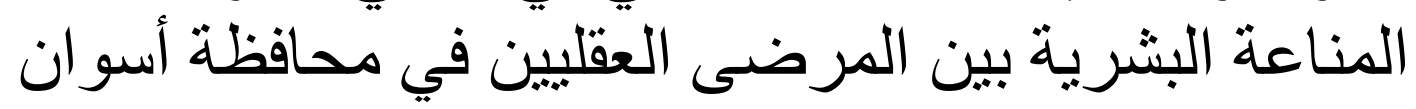

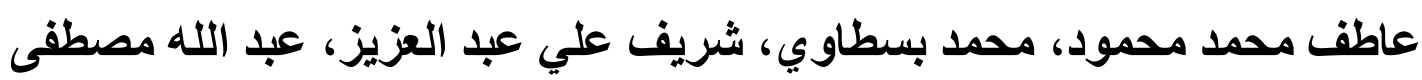
*عفر

قسمي الجهاز الهضمي و الكبد والامراض المعدية والباتولوجيا الاكلينيكية*، كلية الطب، جامعة الأزهر

\section{E-mail: dratef@yahoo.com}

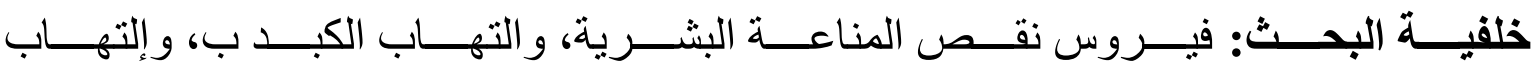

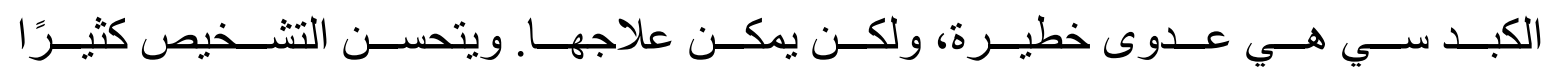

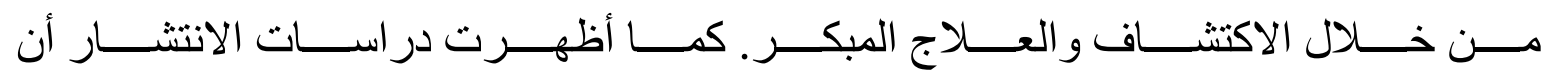

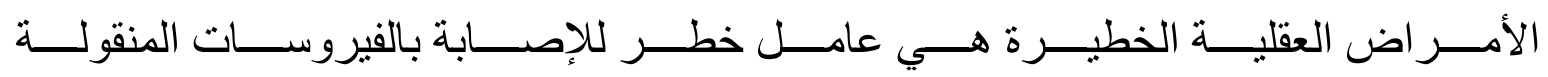

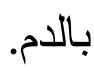

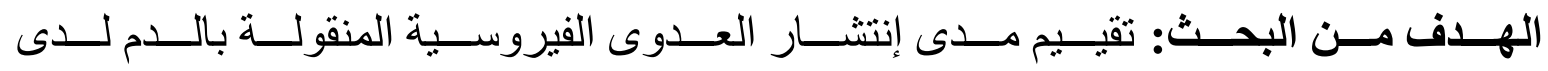
الكصابين بإضطر ابات نفسية في محافظة أسوان.

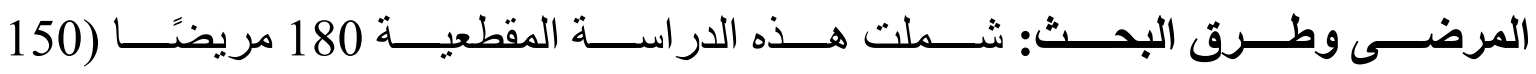

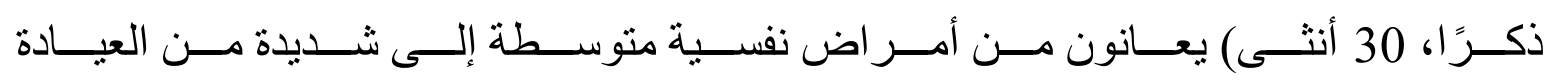

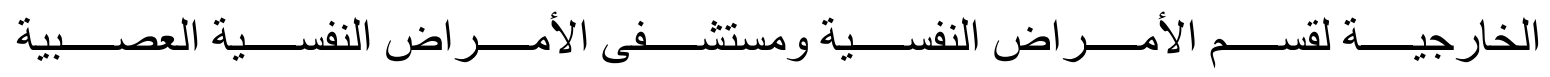

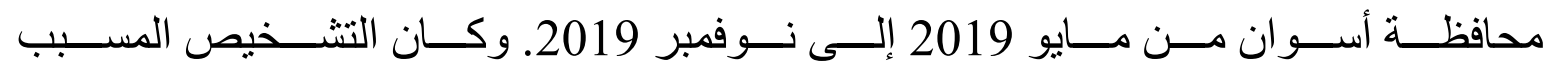

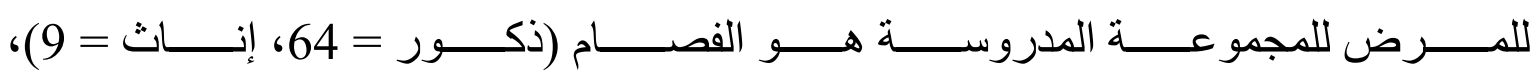

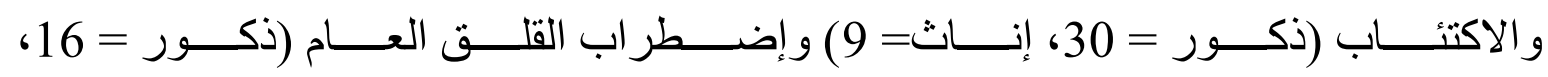

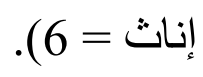

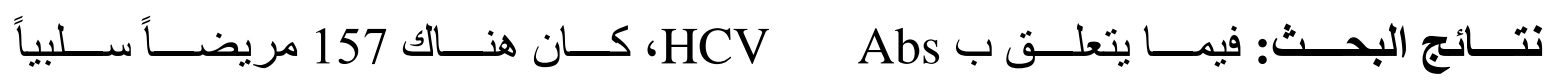

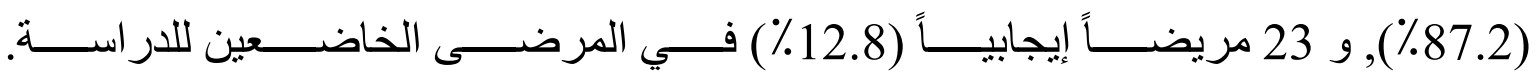

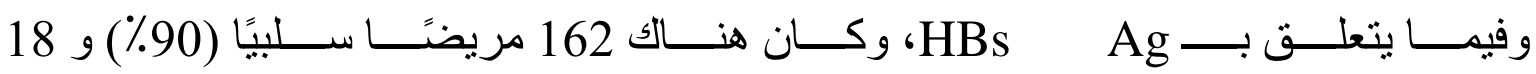




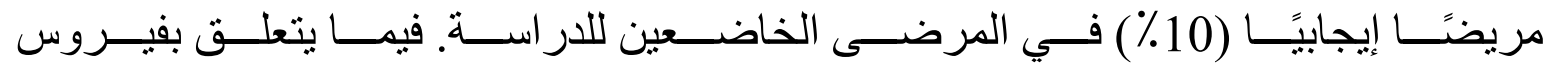

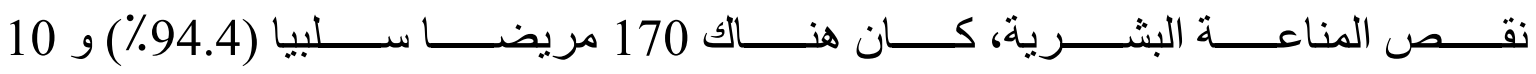

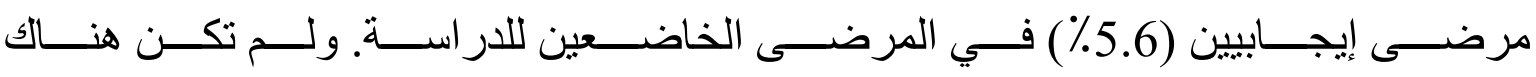

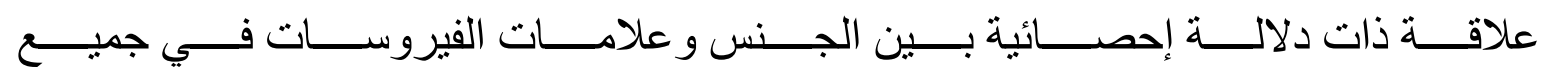
المرضى الخاضعين للار اسة.

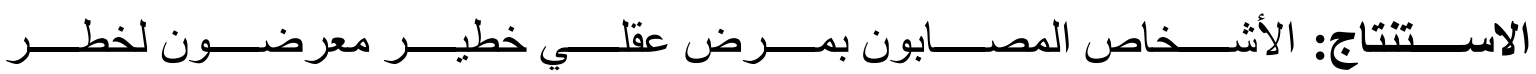

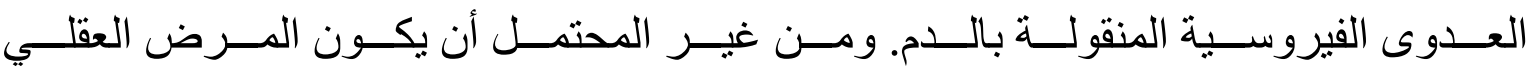

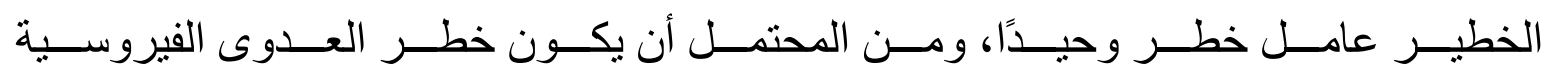

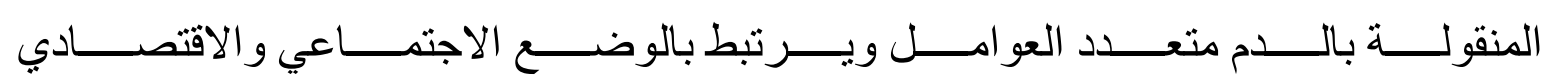

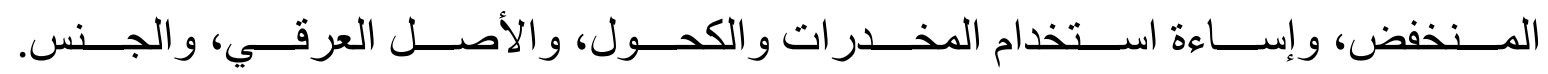

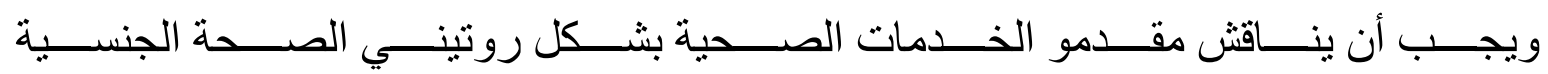

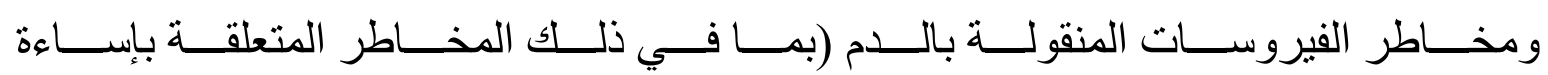

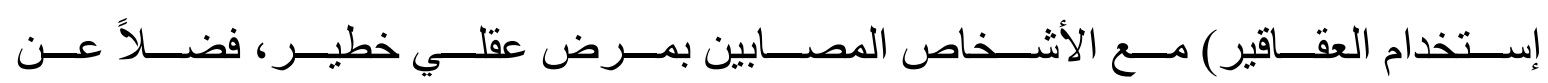

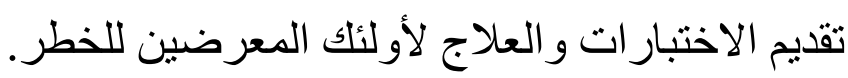

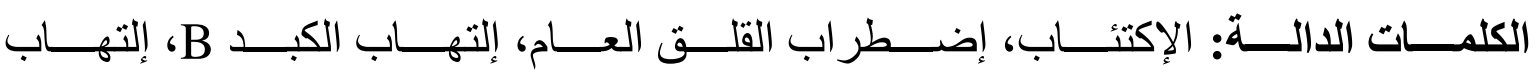
الكبد C، المرض العقلي، الفصام. 